\title{
Production and the prediction of growth
}

By D. J. Thомson, Grassland Research Institute, Hurley, Maidenhead, Berkshire SL6 ${ }_{5} L R$

The question posed by the title of the paper is in essence a simple one: is it possible, from chemical and physical analysis of the diet, to predict the rate of growth of the ruminant animal?

The beguiling simplicity of the question is soon dissipated in view of the ruminant mode of digestion and the transformation of the ingested nutrients to alternate forms for absorption and the subsequent synthesis and retention of complex proteins and fat in the animal body. Shown diagrammatically (Fig. I) the

\section{PREDICTION of GROWTH}

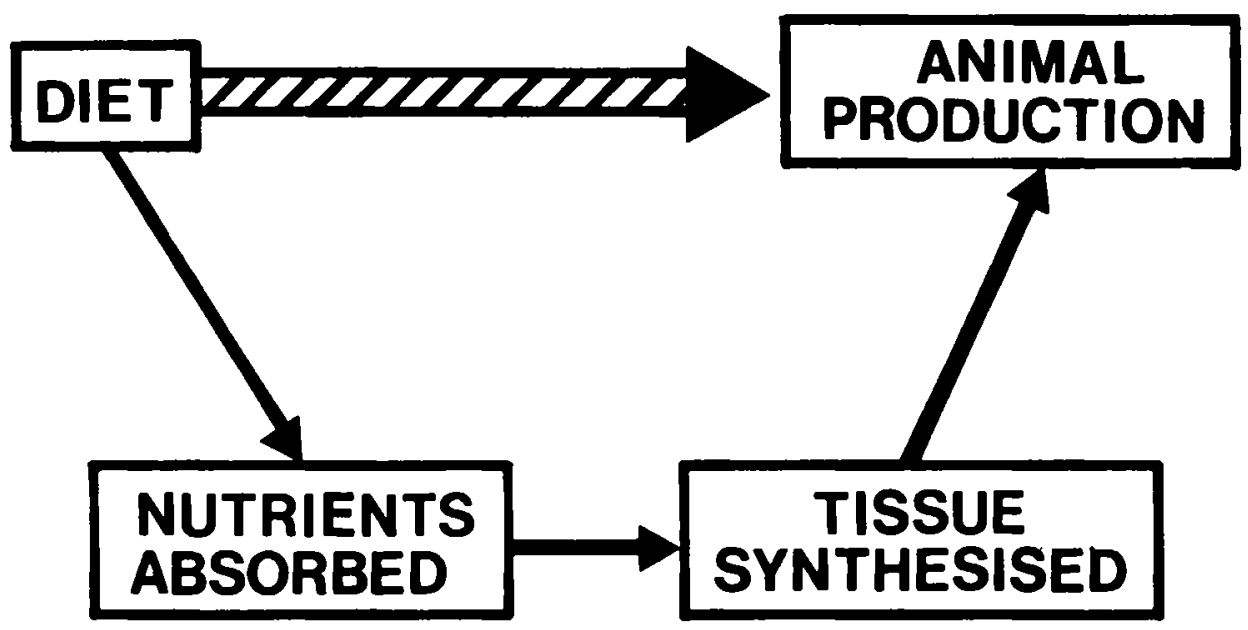

Fig. I. Schematic diagram of the prediction of growth in the ruminant.

direct prediction of growth rate from chemical analysis of the food has perforce in the ruminant to be through measurement and prediction of the nutrients absorbed, the tissue synthesized and the rate of production (growth) that this represents. Further legitimate questions are, who wishes to predict growth, for what purpose and for what period of time? This may dictate the level of accuracy acceptable in the prediction, but not the conceptual basis for the process of prediction. 


\section{Metabolizable energy system}

A method of rationing ruminant livestock, based on the proposals of the Agricultural, Research Council (1965), is currently in use in the U.K. (Ministry of Agriculture, Fisheries \& Food, 1975). This is a variable net energy system based on metabolizable energy (ME as $M J / k g$ dry matter) measured or predicted at the maintenance level of feeding. Knowledge of the DM content of the diet and the live weight $(\mathrm{LW})$ of the animal is also required. The components in the system are $\mathrm{ME}$ concentration, the intake of $M E$, the amount of $M E$ required for maintenance, the efficiency of utilization of the ME for growth and fattening $\left(k_{f}\right)$, the energy stored and the rate of $\mathrm{LW}$ gain that this retained energy represents.

Values for growing lambs fed principally forage diets were used to compare predicted and observed rates of live-weight gain (LWG) (D. J. Thomson, S. B. Cammell and J. S. Fenlon, unpublished observations) on the basis of the ME system

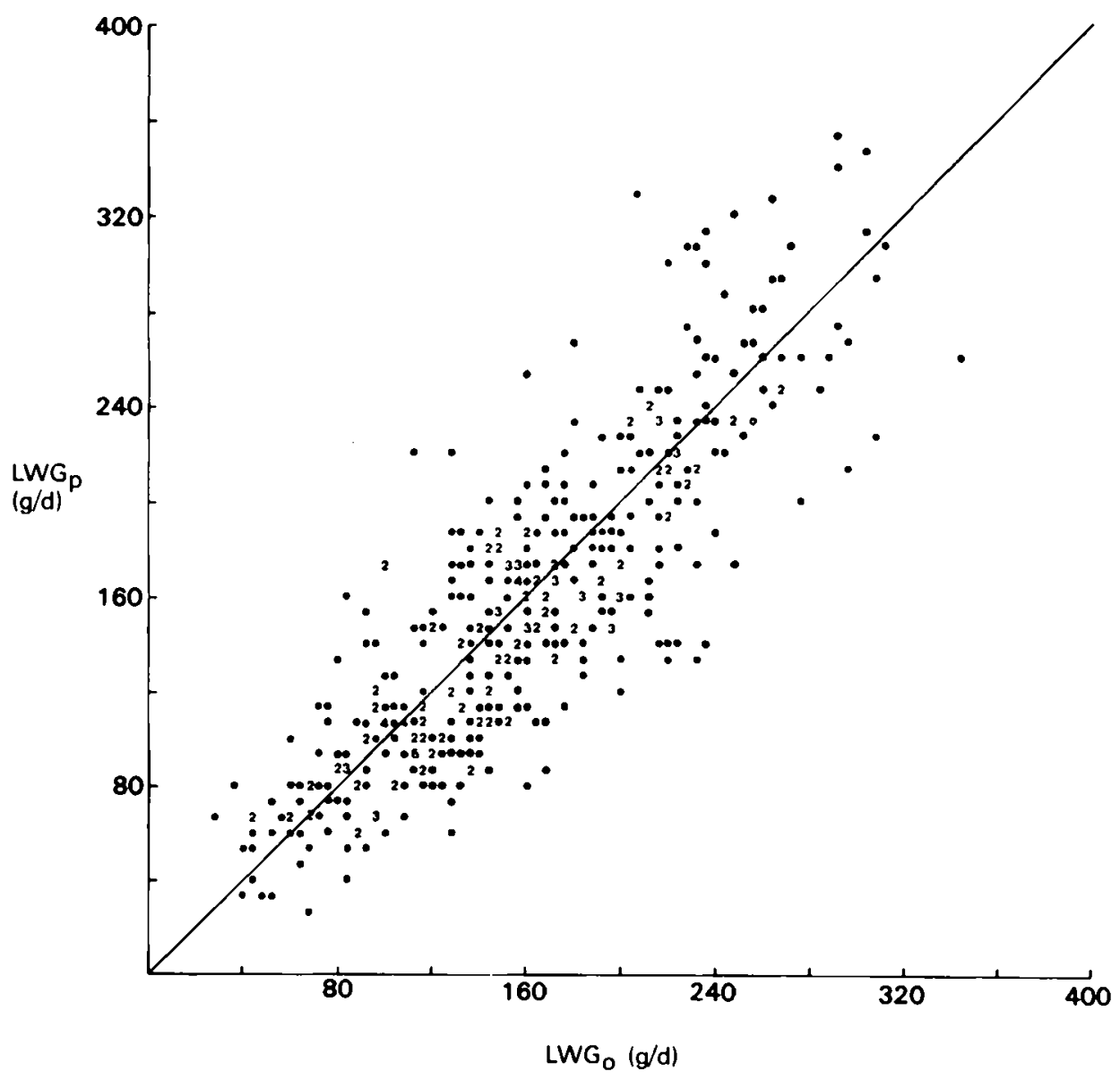

Fig. 2. Comparison of the observed $\left(L W G_{0}\right)$ and predicted $\left(L G W_{p}\right)$ live-weight gain of lambs fed forage and cereal diets.

-Ministry of Agriculture Fisheries and Food (1975). 
(MAFF, 1975), with the ME content of the diet predicted from the equation of Terry et al. (1973)

$$
\text { Digestible energy }=0.123 \mathrm{CP}+0 \cdot 170 \mathrm{D}+0 \cdot 285 \pm 0.324
$$

where $\mathrm{D}$ is the in vitro measurement of the digestibility of the organic matter in the $D M$ and $C P$ is crude protein and ME is obtained from DE $\times 0.815$. In Fig. 2 the predicted $\left(L W G_{p}\right)$ and observed $\left(L W G_{o}\right)$ rates of live-weight gain are shown from experiments conducted at the Grassland Research Institute in which young wormfree lambs, indoors, 8 weeks of age, were fed on known amounts of food for between 70 and $100 \mathrm{~d}$, and gain, energy retention and $k_{f}$ were measured by the comparative slaughter technique (Thomson \& Cammell, 1979). The rate of growth was predicted with an accuracy (SD) of $\pm 33 \mathrm{~g} / \mathrm{d}$. This level of agreement between $L W G_{p}$ and $L W G_{O}$ was achieved by the overestimation of $M E$ intake, $M E$ for maintenance, and $k_{f}$ (chopped forages) being counterbalanced by the estimation of the energy value of each $\mathrm{kg}$ of live-weight gain. Comparison of alternative estimates of the energy content of gain in lambs (National Academy of Sciences, 1975) with those given by the Ministry of Agriculture, Fisheries \& Food (1975) do similarly suggest, at low body-weights, that the UK values are too high at 14.5 , 15.6 and $16.3 \mathrm{MJ} / \mathrm{kg}$ for rates of LWG of 100,200 and $300 \mathrm{~g} / \mathrm{d}$ respectively.

\section{$N$ Supply and ME intake}

It can, and has been proposed that, in the absence of mineral and vitamin deficiencies, worm burdens and unduly inclement climatic or environmental conditions, the rate of growth can be predicted satisfactorily on the basis of protein supply and $M E$ intake. In the case of protein supply being below requirement, $\mathbf{N}$ balance is independent of energy intake, but linearly related to absorbed $\mathbf{N}$ and metabolic body size ( $\mathrm{LW}^{0.75}$ ); if absorbed amino acid $\mathrm{N}$ is in excess of requirement then $\mathrm{N}$ balance in lambs of a constant live weight increased linearly with $\mathrm{ME}$ intake, at a rate that decreased with increasing live weight. This was elegantly demonstrated by Black \& Griffiths (1975) in an analysis of nearly $300 \mathrm{~N}$ retention measurements in lambs receiving liquid diets of varying protein content directly into the abomasum.

The profile of absorbed nutrients for the milk-fed or abomasally infused lamb differs from that available in the fully ruminant animal. Black et al. (1976) using a model of growth (Graham et al. 1976), part of which is based on energy balance calculated from ME according to the methods recommended by the Agricultural Research Council (1965), incorporated the values of MacRae \& Ulyatt (1974) for the absorption of non-ammonia nitrogen for sheep given ryegrass or white clover, and predicted the rates of empty body-weight gain (EBWG) and energy and protein retention and compared these with the measured values obtained by Rattray \& Joyce (1969) for lambs receiving ryegrass or white clover ad lib. The rates of performance predicted by their model agreed very well with those observed by Rattray \& Joyce (1969) for each of the forage species. The difference in EBWG of $3^{8} \mathrm{~g} / \mathrm{d}$ in favour of lambs given white clover was subsequently calculated would be achievable by lambs given ryegrass when the limitation in $\mathbf{N}$ absorption was 
removed, the $M E$ intake was equivalent to that measured for white clover and the energy costs of eating and ruminating (higher for ryegrass) were reduced to those for white clover (Lancashire \& Keogh, 1966; Ulyatt, 1971).

The ability to predict growth rate on the basis of amino acid absorption from the small intestine and energy (ME) supply is, like the recent resolution by Blaxter \& Boyne (1978) of differences in $k_{f}$ at a given value of $q$ (ME at maintenance) for different categories of diets by the inclusion of crude protein in the OM, based on empirical relationships. Crude protein content of the diet is not a satisfactory basis for the prediction of amino acid absorption, nor can ME be considered an adequate parameter for prediction for the variety of energy substrates available for absorption following ruminal and post-ruminal digestion of dietary energy and carbohydrates.

\section{ME: nutrient supply and efficiency of utilization}

A single generalized relationship between ME concentration in the DM (M/D) and $k_{f}\left(k_{f}=0.0435 \mathrm{M} / \mathrm{D}\right)$ is used in the ME system (Ministry of Agriculture, Fisheries \& Food, 1975). Van Es (1976) and Blaxter (1974) have shown that there are several separate relationships between $q$ (ME at maintenance) and $k_{f}$ for growing sheep and cattle and the identifiable categories of diets are primary growth and re-growth forage, pelleted forage, and mixed forage and cereal diets, to which may be added grasses and legumes (Thomson, 1977). The implication of these separate relationships which demonstrate different $k_{f}$ values at any given value of $q$ or $M / D$, is that unitary $M E$ is not used with equal efficiency and different substrates, utilized with varying efficiency for growth and fattening, are derived from the contrasting categories of diets. Does this variation in $k_{f}$, in the absence of a shortfall in the supply of absorbed protein, indicate differences in the balance of absorbed energy available for synthesis? It is appropriate to remember earlier abomasal infusion work (Blaxter, 1962) which demonstrated that the ruminant animal utilizes glucose, amino acids and lipids with higher efficiency than volatile fatty acids for lipogenesis (Table $\mathrm{r}$ ).

Table I. The efficiency of utilization for lipogenesis of glucose, protein lipid and volatile fatty acids

$\begin{array}{lc}\text { Glucose (abomasal infusion) } & \begin{array}{c}\text { kJ energy retained/ } \\ \text { 100 kJ added ME }\end{array} \\ \text { Protein (abomasal infusion) } & 72 \\ \text { Lipid (abomasal infusion) } & 65 \\ \text { Volatile fatty acids (75:15:10) } & 63 \\ \text { ( } 50\end{array}$

There are differences in the amount and rate of carbohydrate digestion in the rumen which can alter both the composition of absorbed energy and the ratio of absorbed protein to absorbed energy in ruminants.

(I) Maize, particularly ground maize, supplies more glucose to the tissues than barley; 
(2) legumes, for instance white clover, in addition to supplying more protein, have a lower total content of cell wall constituents, which are more rapidly digested in the rumen, than that contained in grass of similar digestibility;

(3) grinding and pelleting of forage reduces the amount of energy, organic matter, cellulose and hemi-cellulose digested in the rumen compared with the original material given in the chopped or long form;

(4) forage diets of low digestibility contain more structural carbohydrate than those of high digestibility and the quantity of carbohydrate digested in the rumen differs between these forages of contrasting maturity;

(5) re-growth and autumn harvested grass have different carbohydrate contents, both soluble and structural.

For each of the five examples quoted there are also differences in the efficiency with which the ME contained in these contrasting categories are utilized for growth and fattening. There is, in the context of this Symposium, little doubt that carbohydrate digestion has a major impact on the composition of the nutrients supplied, in addition to any changes in the volatile fatty acids in the rumen, which may or may not influence the efficiency of food utilization. Amino acid supply and glucose absorption can also be manipulated by dietary means to influence $k_{f}$ in a positive manner (Thomson, 1978).

In the knowledge of the variety of carbohydrates, cellulose, hemi-cellulose, lignin, pectin, soluble carbohydrate present in ruminant diets (Morrison, 1979) and the variation in the end products of ruminal digestion (Sutton, 1979), and knowing that $\mathrm{N}$ and $\mathrm{ME}$ content alone constitute an unduly narrow and empirical base for the subsequent prediction of growth: only dynamic and interactive models of ruminant digestion can encompass dietary differences and predict nutrient supply (Baldwin et al. 1977; Beever et al. 1980). To these interactive models simulating carbohydrate and protein digestion the rumen, may be added models of growth based on nutrient composition and accommodating competition of nutrients between functions through the use of Michaelis-Menton kinetics (Black \& Reis, 1979).

This latter development in the simulation of growth appears to overcome some of the problems associated with the development of earlier models of growth (Graham et al. 1976; Black, 1974) based on empirical relationships, or incorporating arbitrary choices of which nutrients are used for which function. The error attached to the prediction of the rate of growth (Fig. 2) may not be acceptable, particularly with future use of a wider spectrum of dietary constituents and crop by-products in ruminant diets.

New rapid infrared reflectance spectrometry methods (Norris et al. 1976) offer a wide range of analysis to assist in the chemical definition of the diet for use with predictive models of nutrient supply and growth by both advisory and research workers.

\section{Conclusion}

Prediction of growth rate in ruminants in the future should be based on better chemical definition of the diet to provide, through interactive models simulating 
carbohydrate and protein digestion in the rumen, measures of the nutrients supplied to the animal, to be used in combination with models of growth based on nutrient composition which accommodate nutrient competition for specific functions.

The author would like to acknowledge helpful discussion with Dr J. L. Black during the preparation of this paper.

\section{REFERENCES}

Agricultural Research Council (1965). The Nutrient Requirements of Farm Livestock No. 2, Ruminants. London: H.M. Stationery Office.

Baldwin, R. L., Koong, L. J. \& Ulyatt, M. J. (1977). Agric. Systems 2, 255.

Beever, D. E., Black, J. L. \& Faichney, G. J. (1980). Agric. Systems (In the Press).

Black, J. L. (1974). Proc. Aust. Soc. Anim. Prod. 10, 211.

Black, J. L., Graham, N. McC. \& Faichney, G. J. (1976). In From Plant to Animal Protein. Reviews in Rural Science II, p. I6I, [T. M. Sutherland, J. R. McWilliams and R. A. Leng, editors]. Armidale: University of New England Publishing Unit.

Black, J. L. \& Griffiths, D. A. (1975). Br. F. Nutr. 33, 399.

Black, J. L. \& Reis, P. J. (1979). Aust. F. biol. Sci. (In the Press).

Blaxter, K. L. (1962). The Energy Metabolism of Ruminants. London: Hutchinson.

Blaxter, K. L. (1974). In Nutrition Conference for Feed Manufacturers, p. 3, [H. Swan and D. Lewis, editors]. London: Butterworths.

Blaxter, K. L. \& Boyne, A. W. (1978). J. agric. Sci., Camb. 90, 47.

Graham, N. McC., Black, J. L., Faichney, G. J. \& Arnold, G. W. (1976). Agric. Systems. 1, 113.

Lancashire, J. A. \& Keogh, R. G. (I966). Proc. N.Z. Soc. Anim. Prod. 26, 22.

MacRae, J. C. \& Ulyatt, M. J. (1974). F. agric. Sci., Camb. 82, 309.

Ministry of Agriculture, Fisheries \& Food (1975). Tech. Bull. No. 33 .

Morrison, J. M. (1979). Proc. Nutr. Soc. 38, 269.

National Academy of Sciences (1975). Nutrient Requirements of Sheep. 5th edn. Washington D.C.: National Academy of Sciences.

Norris, K. H., Barnes, R. F., Moore, J. E. \& Shenk, J. S. (1976). J. Anim. Sci. 43, 889.

Rattray, P. V. \& Joyce, J. P. (1969). Proc. N.Z. Soc. Anim. Prod. 29, 102.

Sutton, J. (1979). Proc. Nutr. Soc. 38, 275.

Terry, R. A., Osbourn, D. F., Cammell, S. B. \& Fenlon, J. S. (1973). Vaxtodling, $28,19$.

Thomson, D. J. (1977). Proc. int. Mtg. Anim. Prod. Temperate Grassld. p. 131. Dublin: An Foras Taluntais.

Thomson, D. J. (1978). In Ruminant Digestion and Feed Evaluation, p. 12.1. London: Agricultural Research Council.

Thomson, D. J. \& Cammell, S. B. (1979). Br. F. Nutr. 41, 297.

Ulyatt, M. J. (1971). N.Z. F. agric. Res. 14, 352.

van Es, A. J. H. (1976). In Principles of Cattle Production, p. 237, [H. Swan and W. H. Broster, editors]. London: Butterworths. 